\title{
Kemampuan Keaksaraan Anak Usia 5-6 Tahun dalam Penerapan Metode Spalding di TK Quantum Indonesia
}

\author{
Ai Listriani ${ }^{\otimes_{1}}$, Hapidin ${ }^{2}$, Tjipto Sumadi ${ }^{3}$ \\ Pendidikan Anak Usia Dini, Universitas Negeri Jakarta \\ DOI: $10.31004 /$ obsesi.v5i1.680
}

\begin{abstract}
Abstrak
Kemampuan keaksaraan pada anak usia dini merupakan kemampuan awal dan fondasi dasar yang diperlukan anak agar mampu belajar menulis, membaca, dan berhitung. Penelitian ini bertujuan untuk menjelaskan pola kemampuan keaksaraan anak usia 5-6 tahun yang mengalami penerapan metode Spalding di Taman Kanak-kanak Quantum Indonesia. Metode penelitian menggunakan metode kualitatif dengan pendekatan studi kasus. Data bersifat deskriptif berupa catatan kata-kata tertulis dari informan yaitu satu orang guru dan lima orang peserta didik kelompok B (usia 5-6 tahun). Analisis data dalam penelitian ini menggunakan model penjodohan pola Campbell yang didalamnya terdapat tiga alur kegiatan yang dilakukan yaitu pernyataan umum, pemilihan pertanyaan, dan pengembangan peta konsep. Hasil penelitian menunjukkan bahwa kemampuan keaksaraan anak yang muncul dalam penerapan metode Spalding yaitu kemampuan anak menguasai pengetahuan huruf dan kata, kemampuan dasar menulis, serta ketertarikan terhadap tulisan. Berdasarkan penelitian tersebut dinyatakan bahwa kemampuan keaksaraan anak usia 5-6 tahun di TK Quantum Indonesia dapat berkembang dalam penerapan metode Spalding.
\end{abstract}

Kata Kunci: kemampuan keaksaraan; metode spalding; anak usia dini.

\begin{abstract}
Literacy ability in early childhood is the initial ability and basic foundation needed by children to be able to learn to write, read, and count. This study aims to explain the pattern of literacy skills of children aged 5-6 years who experience the application of the Spalding method in Kindergarten of Quantum Indonesia. The research method uses qualitative methods with a case study approach. The data is descriptive in the form of written notes from informants, namely one teacher and five group B students (ages 5-6 years). Analysis of the data in this study uses a Campbell pattern matching model in which there are three lines of activity carried out, namely general statements, question selection, and the development of concept maps. The results showed that children's literacy abilities that emerged in the application of the Spalding method were children's ability to master letter and word knowledge, basic writing skills, and interest in writing. Based on this research stated that the literacy ability of children aged 5-6 years at Kindergarten of Quantum Indonesia can develop in the application of the Spalding method.
\end{abstract}

Keywords: literacy ability; spalding method; early childhood.

Copyright (c) 2020 Ai Listriani, Hapidin, Tjipto Sumadi

$\triangle$ Corresponding author :

Email Address : ai_listriani@yahoo.com (Bekasi, Jawa Barat)

Received 25 Juli 2020, Accepted 26 Juli 2020, Published 28 Juli 2020 


\section{PENDAHULUAN}

Pendidikan anak usia dini merupakan suatu program pembinaan dalam bentuk rangsangan stimulasi yang ditujukan bagi anak usia nol hingga enam tahun. Pendidikan anak usia dini memiliki urgensi dan peranan penting karena bentuk pendidikan yang dilakukan menghasilkan fondasi dasar bagi kepribadian dan kemampuan yang diperlukan anak agar memiliki kesiapan di jenjang pendidikan selanjutnya (Susanto, 2018). Salah satu kemampuan yang harus dikuasai anak usia dini adalah kemampuan dasar menulis dan awal membaca. Di dalam kurikulum 2013 PAUD dinyatakan dasar kemampuan menulis dan awal membaca diistilahkan sebagai kemampuan keaksaraan dimana anak mampu mengenal huruf, mengenal simbol huruf, menghubungkan bunyi huruf dan simbolnya, serta menulis nama sendiri dan kata sederhana yang dikenalnya (Yunita, Kurnia, \& Chairilsyah, 2020). Berbicara tentang keaksaraan, dalam pendidikan dasar dinyatakan (Borre et al., 2019) bahwa keaksaraan sebagai kunci bagi anak usia dini dan merupakan fondasi untuk mereka belajar tidak hanya membaca dan menulis namun dalam bidang akademik lainnya. Keaksaraan disebut juga dengan istilah literasi yang dimaknai sebagai kemelekan huruf, mengenal tulisan, serta dapat membaca tulisan (Nahdi \& Yunitasari, 2019).

Kemampuan keaksaraan sangat penting dibangun sedini mungkin sesuai dengan tahapan usia anak agar kemampuan bahasa anak berkembang yang kemudian berpengaruh pada pribadi anak di masyarakat (Matin, Rohaety, \& Nuraeni, 2019). Teale dan Sulzby (1986) dalam (Pinto, Bigozzi, Vezzani, \& Tarchi, 2017) jelas menyatakan bahwa anak-anak belajar tentang literasi jauh sebelum sekolah formal, sebuah perspektif ini kemudian didefinisikan sebagai literasi dini atau keaksaraan awal. Selanjutnya keaksaraan dalam (Purnama, 2019) dinyatakan bahwa bukan sebagai sebuah pelajaran melainkan hal wajar yang terdapat dalam pengalaman main anak dengan bahan yang tepat dan orang dewasa yang bisa menerima usaha setiap anak untuk mengeksplorasi terkait huruf, cetakan, dan makna bacaan. Keaksaraan dinyatakan sebagai proses anak-anak belajar tentang pengetahuan dan keterampilan menggunakan tanda dan simbol untuk berkomunikasi melalui interaksi dengan difasilitasi media alat dan dukungan budaya sosial (Neumann, Finger, \& Neumann, 2017). Berdasarkan pernyataan tersebut, dapat disimpulkan bahwa kemampuan keaksaraan pada anak usia dini terkait pengetahuan tentang huruf, kata, tulisan, dan bacaan sebagai bagian dari perkembangan bahasa anak yang dapat dikuasai sejak dini agar menjadi fondasi untuk belajar menulis, membaca, dan bidang akademik lainnya.

Adapun optimalisasi pencapaian kemampuan keaksaraan anak pada pendidikan anak usia dini salah satunya bergantung pada metode pembelajaran yang digunakan oleh guru. Hal ini berdasarkan penelitian (Rahmatika, Hartati, \& Yetti, 2019) yang menyatakan bahwa pada kelompok anak usia 5-6 tahun masih terdapat anak yang kesulitan mengenal huruf, merangkai huruf menjadi kata, dan adanya kesulitan guru dalam menerapkan metode yang menarik minat anak untuk menguasai keaksaraan secara optimal. (Mardliyah, Siahaan, \& Budirahayu, 2020) menyatakan peran dan keterampilan guru dalam memilih dan menerapkan metode pembelajaran sangat berpengaruh pada terjadinya proses perkembangan anak yang optimal. Berbicara tentang metode pembelajaran untuk menggali kemampuan keaksaraan anak, terdapat ragam metode yang digunakan guru untuk menyelenggarakan pembelajaran pada anak usia dini, diantaranya metode Montessori (Darnis, 2018). Metode ini menekankan salah satunya pada materi akademik untuk pengajaran menulis, membaca, dan matematika. Kelebihan metode Montessori yaitu fokus pada kemandirian individu anak, aktivitas stimulasi mengenai kemampuan menulis dan membaca secara terstruktur tertulis dalam prosedur yang telah ditetapkan, serta semua aktivitas stimulasi tersebut telah disiapkan alat dan bahan khusus (Morrison, 2012). Meskipun metode Montessori ini sangat unggul, namun di sisi lain terdapat kelemahan diantaranya guru perlu sangat ahli dan menguasai tahapan metode ini, serta diperlukan alat dan bahan khusus agar metode Montessori ini optimal dilakukan. Selanjutnya selain metode Montessori, terdapat pula metode pembelajaran mind map yang dinyatakan dalam penelitian (Rahmatika et al., 2019) dapat mengembangkan 
kemampuan membaca permulaan anak. Metode pembelajaran mind map merupakan metode yang mengaktifkan otak kiri dan kanan, serta membantu menyimpan informasi dengan sistem peta pikiran. Metode mind map memiliki keunggulan visualisasi tulisan, gambar, dan kata secara penuh warna dan menarik minat anak untuk membaca (Rahmatika et al., 2019).

Selanjutnya selain metode pembelajaran yang diuraikan di atas, terdapat pula metode pembelajaran Spalding yang digunakan oleh lembaga Taman Kanak-kanak Quantum Indonesia yang berada di Kota Bekasi Jawa Barat. Berdasarkan studi pendahuluan yang dilakukan pada bulan November 2019, metode Spalding ini diterapkan di TK Quantum Indonesia sejak tahun pelajaran 2017/2018 untuk mengoptimalkan pengembangan bahasa terutama kemampuan keaksaraan dengan berpedoman langsung pada buku "The Writing Road to Reading, Spalding Method" yang ditulis oleh Romalda Bishop Spalding pada tahun 1957. Fenomena menarik yang ditemukan dari penerapan metode Spalding di TK Quantum Indonesia ini yaitu antusiasme anak saat mendengar dan menyimak guru bercerita sangat tinggi dan konsisten, guru bercerita tentang isi buku/gambar/benda sebagai topik bahasan pada hari itu dengan begitu kreatif sehingga menarik minat dan perhatian anak. Rata-rata anak sudah memiliki perbendaharaan kosakata yang memadai, terlihat dari kemampuan menceritakan kembali secara sederhana dari cerita yang telah diperdengarkan. Setelah tahap bercerita atau membaca lantang selesai dilaksanakan, terdapat kegiatan membunyikan setiap huruf dari suatu kata yang ditunjukkan dilengkapi dengan gambar dan tulisan, kata yang diambil berkaitan dengan bahan cerita/bacaan yang sebelumnya disampaikan. Selanjutnya kegiatan yang teramati adalah adanya aktivitas anak menghubungkan bunyi huruf yang didiktekan oleh guru dengan simbol/cetakan huruf kemudian merangkainya menjadi kata, pada aktivitas ini anak-anak antusias karena dikelola dalam bentuk permainan. Hal menarik lainnya adalah pada saat kegiatan menulis membentuk huruf, di dalam metode Spalding ini rupanya terdapat tata cara menulis membentuk setiap huruf. Aturan penulisan yang dimaksud yaitu menggunakan analogi angka dan gambar arah dalam sebuah jam.

Adapun penerapan metode Spalding di Indonesia, berdasarkan pencarian secara terbatas melalui daring belum banyak yang menggunakannya, namun penelitian mengenai penerapan metode Spalding ini sebelumnya pernah dilakukan oleh (Latifah, 2015) yaitu menggunakan metode Spalding melalui media gambar untuk meningkatkan kemampuan menulis puisi bebas pada siswa kelas 5 di SDN Babakan Ciparay 1 Kota Bandung. Penelitian tersebut dilakukan melalui metode Penelitian Tindakan Kelas yang dilakukan selama dua siklus dan dinyatakan bahwa terdapat keberhasilan dengan diterapkannya metode Spalding melalui media gambar yang berdampak pada peningkatan kemampuan siswa dalam menulis puisi bebas.

Berdasarkan beberapa fenomena menarik dari adanya penerapan metode Spalding di TK Quantum Indonesia yang diuraikan di atas dan terbatasnya penelitian tentang metode Spalding ini, maka dilaksanakan penelitian lanjutan mengenai kemampuan keaksaraan anak di TK Quantum Indonesia dalam konteks penerapan metode Spalding dengan fokus penelitian adalah menggambarkan pola kemampuan keaksaraan anak kelompok usia 5-6 tahun. Adapun sub fokus dalam penelitian ini yaitu mengenai kemunculan kemampuan keaksaraan anak dan proses penerapan metode Spalding di TK Quantum Indonesia.

\section{METODOLOGI}

Penelitian ini dilaksanakan di TK Quantum Indonesia Kota Bekasi selama dua minggu pada bulan Juni tahun pelajaran 2019/2020. Penelitian dilaksanakan dalam kondisi Pembelajaran Jarak Jauh. Metode penelitian yang digunakan dalam penelitian ini adalah metode kualitatif dengan pendekatan studi kasus. Metode kualitatif adalah penelitian yang dimaksudkan untuk memahami fenomena tentang apa yang dialami oleh subjek penelitian secara holistik dengan cara deskriptif dalam bentuk kata-kata dan bahasa pada suatu konteks khusus yang alamiah (Moleong, 2016). Studi kasus (case study) merupakan penelitian yang dilakukan terhadap suatu kesatuan sistem baik berupa program, kegiatan, peristiwa atau 
kelompok individu yang terikat oleh tempat, waktu atau ikatan tertentu. Sumber data utama dalam penelitian kualitatif ialah kata-kata, dan tindakan. Sedangkan selebihnya adalah data tambahan seperti dokumen dan lain-lain (Moleong, 2016). Berdasarkan hal itu, maka data dalam penelitian ini adalah kata-kata dan tindakan. Yang menjadi data adalah kemampuan keaksaraan anak yang mengalami penerapan metode Spalding sebanyak lima peserta didik. Sementara sumber datanya adalah dari subyek penelitian (informan) yaitu satu orang guru yang mengetahui kemampuan keaksaraan anak dan menguasai penerapan metode Spalding. Metode pengumpulan data yang digunakan dalam penelitian ini terdiri dari observasi partisipan saat pembelajaran daring, wawancara tidak terstruktur dengan guru via daring, dan tambahan dokumentasi.

Setelah mengumpulkan data yang dibutuhkan dalam penelitian, langkah selanjutnya yang harus dilakukan adalah melakukan analisis data yang merupakan proses mengatur urutan data, mengorganisasikannya ke dalam suatu pola, kategorisasi dan satuan uraian dasar. Analisis data dilakukan untuk mengkaji dan mengolah data yang telah terkumpul agar memperoleh simpulan yang sesuai dengan tujuan penelitian. Teknik analisis data yang digunakan dalam penelitian ini adalah dengan menggunakan model penjodohan pola Campbell. Penjodohan pola adalah membandingkan pola secara empiris dengan pola yang diprediksikan. Jika pola-pola menunjukkan kesamaan, maka hasil data dapat memperkuat validitas internal studi kasus yang bersangkutan (Yin, 2015). Pada model penjodohan pola Campbell terdapat tiga alur kegiatan yang akan dilakukan, yaitu pernyataan umum, pemilihan pertanyaan dan pengembangan peta konsep.

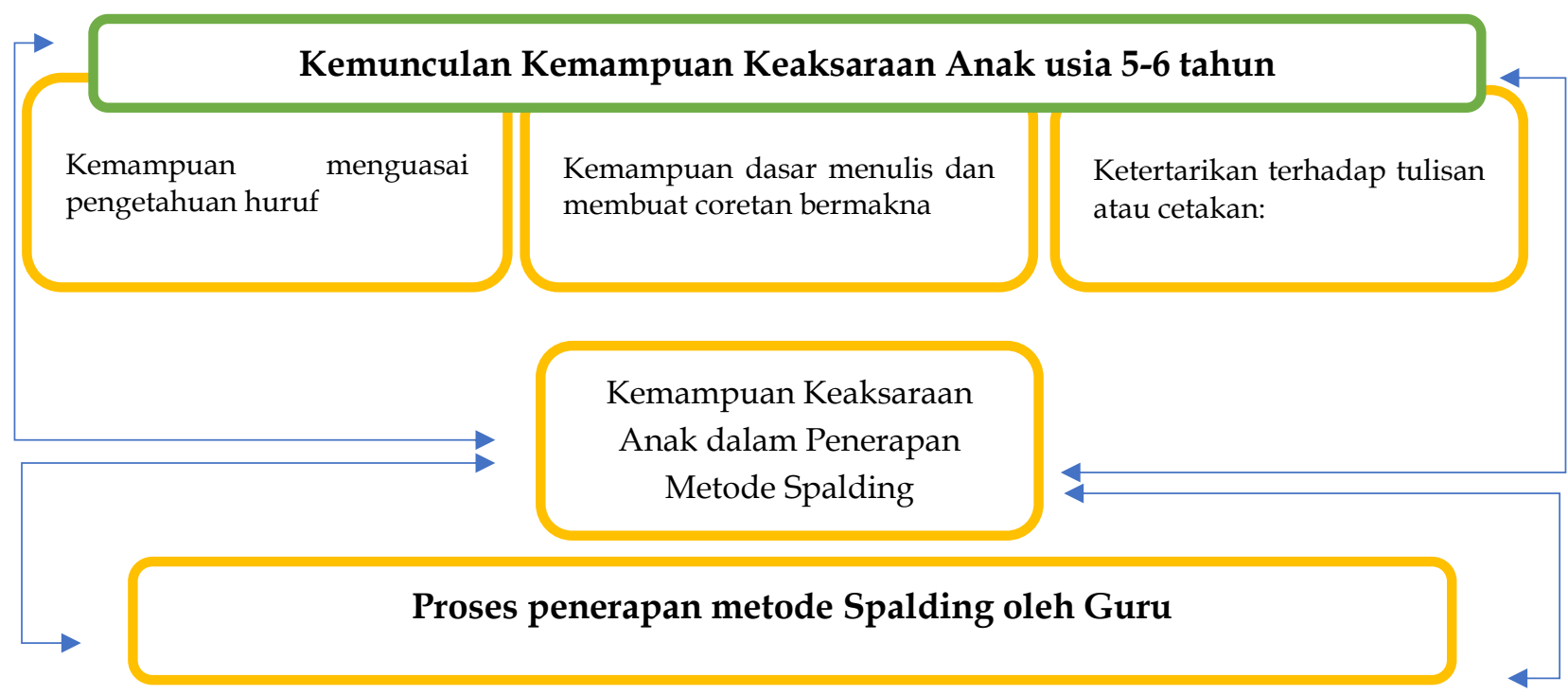

Gambar 1. Peta Konsep kemampuan Keaksaraan Anak dalam Penerapan Metode Spalding

Peta konsep di atas menunjukkan jika setiap pernyataan umum memiliki pola-pola yang terbentuk. Pernyataan umum dipilih yang memiliki kecenderungan adanya keterikatan dengan kemampuan keaksaraan siswa dan tindakan guru dalam menerapkan metode Spalding. Setiap pernyataan akan dihubungkan dengan kemunculan kemampuan keaksaraan anak usia 5-6 tahun dan proses penerapan metode Spalding yang dilakukan guru. Berdasarkan peta konsep di atas, terdapat pola-pola keterkaitan dan saling berhubungan yang dapat dibangun rumusan teoritik mengenai kemunculan kemampuan keaksaraan pada anak kelompok B sebagai berikut: 1) anak mampu menguasai pengetahuan tentang huruf, 2) anak mampu menguasai dasar menulis dan membuat coretan bermakna, 3) anak memiliki ketertarikan terhadap tulisan atau cetakan kata sederhana. Berdasarkan peta konsep di atas pun, kemudian dapat dibangun rumusan teoritik mengenai proses penerapan metode Spalding yang dilakukan guru. 


\section{HASIL DAN PEMBAHASAN}

Penelitian ini dilaksanakan di TK Quantum Indonesia Kota Bekasi. Penelitian mengenai kemampuan keaksaraan ini dilakukan terhadap peserta didik di kelompok B pada tahun pelajaran 2019/2020 sejumlah lima peserta didik. Berdasarkan data yang diperoleh dari catatan lapangan, catatan wawancara dan catatan dokumentasi terdapat beberapa pernyataan yang membentuk keterkaitan pola mengenai kemampuan keaksaraan anak usia 5-6 tahun yang mengalami penerapan metode Spalding. Berikut data hasil temuan di lapangan:

\section{Kemampuan Menguasai Pengetahuan Tentang Huruf dan Kata}

Kemunculan kemampuan keaksaraan yang ditunjukkan oleh siswa kelompok B yaitu siswa AF, AH, NA, AL, dan SG diantaranya dapat mengenal semua huruf konsonan dan vokal, menghubungkan bunyi huruf dan simbol huruf, menyebutkan huruf yang terdapat pada kata sederhana yang diucapkan secara lisan oleh guru maupun berdasarkan gambar, serta mulai mengenal bunyi huruf yang kompleks seperti gabungan huruf konsonan "ng" dan "ny" serta diftong "ai" dan " au".

Berdasarkan temuan lapangan tersebut, dapat dinyatakan bahwa kemampuan keaksaraan siswa AF, AH, NA, AL, dan SG selaras dengan teori yang dinyatakan oleh Dodge, Colker dan Heroman (Susanto, 2011) bahwa keaksaraan awal adalah bagaimana anak belajar dasar-dasar kemampuan untuk dapat membaca, menulis dan memahami bahasa tulis, yang mencakup kesadaran fonologis yaitu menyimak dan membedakan antara bunyi suara dari kata yang dilafalkan; penguasaan terhadap cetakan yaitu belajar bagaimana kerja dari cetakan/tulisan; dan e). pengetahuan tentang huruf dan kata; mengidentifikasi dan menulis beberapa huruf dan kata; serta g). Pemahaman anak terhadap buku dan teks lainnya, dan minat membaca yaitu belajar mengenali tulisan dari beragam teks. Teori lain pun menyatakan awal anak siap membaca ditandai dengan pengetahuan huruf yang memadai sesuai pernyataan (Maqdalena \& Widiastuti, 2018) bahwa mengenal simbol huruf adalah suatu hal yang penting untuk kesiapan belajar membaca di jenjang pendidikan dasar, dan (Winarti \& Suryana, 2020) pun menyatakan bahwa membaca adalah proses menginterpretasikan simbol huruf menjadi suara yang menggambarkan kata yang kemudian kata ini dipelajari dan dipahami. Berdasarkan data temuan lapangan dan teori yang mendukung tersebut, maka kemampuan mengenai pengetahuan huruf yang telah dimiliki anak di kelompok B TK Quantum Indonesia ini dinyatakan mencapai taraf memadai dan merupakan satu indikator untuk selanjutnya anak siap belajar membaca.

\section{Kemampuan Dasar Menulis dan Membuat Coretan Bermakna.}

Kemampuan keaksaraan yang selanjutnya dimiliki siswa AF, AH, NA, AL, dan SG pada aspek menguasai dasar menulis dan membuat coretan bermakna terlihat dari kemampuan siswa sama rata dalam kemampuan menggenggam pensil, menulis dari kiri ke kanan buku, posisi tubuh saat menulis, dan sama pola saat menunjukkan kemampuan membentuk huruf. Mereka telah dengan lancar menulis nama sendiri, menulis kata sederhana berdasarkan gambar. Selain itu, terdapat kesamaan rupa bentuk huruf yang dibuat oleh siswa. Kemampuan membuat coretan bermakna yang menjadi kelebihan mereka yaitu mampu menulis dikte untuk kata sederhana yang terdiri dari dua dan tiga suku kata.

Berdasarkan hasil temuan lapangan yang diuraikan di atas, kemampuan siswa membuat coretan bermakna sesuai dengan tahapan menurut Brewer dimana ada 4 tahapan dalam kemampuan menulis, yaitu: a) tahap mencoret atau membuat goresan; b) tahap pengulangan linear, pada tahap ini anak menelusuri bentuk tulisan yang horizontal; c) tahap menulis random, pada tahap ini anak belajar tentang berbagai bentuk yang merupakan suatu tulisan dan mengulang berbagai kata ataupun kalimat; d) tahap menulis nama, pada tahap ini anak mulai menyusun dan menghubungkan antara tulisan dan bunyinya (Dhieni, 2013). Dalam hal ini, kemampuan siswa telah berada di fase menulis nama, dimana telah mampu menyusun dan menghubungkan anatra tulisan dengan bunyinya, dimana fase ini merupakan 
pencapaian kemampuan keaksaraan yang sangat memadai bagi anak usia taman kanakkanak. Hal ini dipertegas oleh pernyataan High Scope Child Observation Record (Zuhrita \& Mufidati, 2017) yang menyebutkan bahwa kegiatan menulis sebagai bagian keaksaraan awal mencakup anak mencoba teknik menulis menggunakan lekuk-lekuk dan garis sebagai huruf, meniru tulisan atau meniru huruf-huruf yang dapat dikenal, menulis nama sendiri, dan menulis beberapa kata.

\section{Ketertarikan Terhadap Tulisan atau Cetakan}

Kemampuan keaksaraan yang berikutnya muncul dan teramati saat proses penelitian berlangsung adalah ketertarikan terhadap tulisan atau cetakan kata yang ditunjukkan guru. Pada kemampuan ini, siswa AF, NA, dan AL sudah menguasai kemampuan membaca cetakan hingga 3 kata yang terangkai menjadi kalimat sederhana, sedangkan siswa AH dan SG sudah mengusaia membaca kata yang tercetak terdiri dari 2 hingga 3 suku kata. Berdasarkan temuan lapangan tersebut, kemampuan keaksaraan yang dimunculkan siswa jika dilihat dari teori merupakan bagian dari komponen kemampuan keaksaraan (emergent literacy) yang dinyatakan oleh Whitehurst dan Lonigan (Tjoe, 2012) yaitu diantaranya; convention of print, dimana anak membaca melalui penemuan cetak; knowledge of letters yaitu kemampuan anak mengidentifikasi huruf; korespondensi phoneme-grapheme, dimana anak sudah memahami bagaimana mensegmentasikan beragam suara bahasa sesuai dengan huruf tertulis; motivasi print, yaitu anak tertarik dalam membaca dan menulis atau mengajukan pertanyaan tentang tulisan/cetakan. Hal ini pun selaras dengan pernyataan (Christianti, 2015) bahwa kesadaran terhadap keaksaraan pada anak usia dini ditunjukkan dengan anak senang dengan bacaan di buku cerita, senang dengan tulisan, paham bahwa tulisan memiliki makna, dan menggunakan huruf untuk mereprestasikan bahasa tulisan. Berdasarkan data dan teori yang dinyatakan di atas, maka dapat disimpulkan bahwa ketertarikan siswa AF, AH, NA, AL, dan SG terahdapa tulisan atau cetakan kata merupakan kemampuan keaksaraan sebagai bagian dari indikator kesiapan membaca yaitu pada aspek motivasi print dimana anak menunjukkan ketertarikan untuk mampu membaca setiap tulisan yang ditunjukkan.

\section{Proses Penerapan Metode Spalding yang Dilakukan Guru}

Kemampuan keaksaraan yang berhasil dimiliki siswa Kelompok B merupakan bentuk dari upaya guru W konsisten menguatkan pengetahuan tentang huruf kepada siswa dengan cara mengulangi mengucapkan bunyi huruf yang disebut maupun saat ditulis. Hal ini berdampak pada meningkatnya dan semakin kuatnya penguasaan anak terhadap bunyi dan simbol huruf. Selanjutnya karena adanya program lembaga yang mengharuskan guru TK-B mengenalkan tata cara menulis huruf dengan aturan metode Spalding, guru W pun konsisten menerapkan metode Spalding ini melalui mencontohkan menulis membentuk huruf dengan metode Spalding. Karena konsistensi guru W inilah yang akhirnya di lapangan teramati ada kesamaan rupa bentuk tulisan siswa. Selama proses penelitian berlangsung, Guru seringkali memberi bantuan yang sesuai dengan tarap kebutuhan siswanya. Hal ini terlihat ketika siswa kesulitan membaca kata yang terdapat huruf gabungan ny dan ng, dan guru membantu mencontohkan bacaan dengan mengeja membunyikan suku katanya.

Berdasarkan data di lapangan tersebut, terlihat bahwa pola penerapan metode Spalding yang dilakukan guru adalah menerapkan latihan dan penguatan terhadap pengetahuan huruf dan bunyi huruf. Hal ini pun terlihat berhubungan dan saling keterkaitan saat guru melatih kegiatan menulis membentuk huruf dengan tetap membunyikan setiap huruf yang ditulis. Penerapan metode Spalding yang dilakukan guru ini pun sesuai dengan prinsip metode Spalding itu sendiri dimana pendekatannya adalah menekankan pada pengenalan kata melalui proses mendengarkan bunyi huruf dan menggaktifkan multisensori dimana anak diajak untuk melihat secara visual, mendengar bunyi huruf, dan melakukan membentuk huruf (Spalding, 2012). Pendekatan fonetik merupakan cara mengenalkan 
pengetahuan huruf yaitu dengan mengenalkan bunyi huruf secara berulang bersamaan dengan latihan membentuk huruf sehingga proses mengenal huruf dilakukan efektif yaitu bunyi huruf dihubungkan dengan simbol huruf dan cara menulis membentuk hurufnya. Proses mengenal pengetahuan huruf dengan mengenalkan bunyi huruf adalah tahap awal yang tepat sebagaimana dinyatakan dalam jurnal (Sukma, Kurnia, \& Febrialismanto, 2020)bahwa dengan mengenalkan bunyi huruf anak akan semakin akrab dengan huruf/aksara. Berdasarkan gambaran proses yang dilakukan guru tersebut pun dapat dinyatakan bahwa guru sedang menstimulasi keaksaraan sebagai kesiapan untuk anak mampu belajar menulis dan membaca. Hal ini diperkuat oleh pernyataan (Fahrurrozi, 2017) bahwa kegiatan membaca yang disuarakan bertujuan agar dapat mengenal huruf dan membunyikannya secara tepat sedangkan menterjemahkan huruf terkait dengan kemampuan memahami huruf yang dibaca.

Selanjutnya, berdasarkan data di atas dapat dilihat bahwa prinsip lain metode Spalding yang diterapkan di TK Quantum Indonesia yaitu menggunakan pendekatan multisensori, dimana saat metode ini dilakukan mengakomodir berbagai sensori yaitu mendengar, melihat, melafalkan/membaca, dan menulis (Spalding, 2012). Prinsip multisensori dalam metode Spalding ini selaras dengan prinsip metode montessori yang menyatakan proses paling tepat dan efektif bagi anak adalah mengaktifkan pancaindera anak. Pendekatan multisensori ini pun dalam penelitian (Simanjuntak, Widyana, \& Astuti, 2020) dinyatakan efektif sebagai metode pengajaran pra membaca bagi anak usia dini karena secara simultan mata, telinga, dan gerakan tangan mendukung anak belajar aksara lebih cepat.

\section{SIMPULAN}

Kemampuan keaksaraan anak dapat dipengaruhi oleh adanya penerapan metode Spalding. Hal ini dapat dilihat dari kemampuan menguasai pengetahuan tentang huruf dan kata, kemampuan dasar menulis dan membuat coretan bermakna, serta ketertarikan terhadap tulisan/cetakan. Peran guru dalam mengembangkan kemampuan keaksaraan adalah salah satu komponen penting. Guru melakukan proses pengulangan dan penguatan bunyi huruf dihubungkan dengan simbol, konsisten mencontohkan menulis membentuk huruf dengan aturan metode Spalding, serta mengakomodir ketertarikan anak terhadap bacaan.

\section{UCAPAN TERIMA KASIH}

Ucapan terima kasih peneliti kepada pembimbing yang telah membantu menyempurnakan penelitian ini, serta ucapan terima kasih kepada TK Quantum Indonesia yang menjadi tempat belajar tentang metode Spalding sebagai salah satu metode yang digunakan untuk menggali keaksaraan yang sesuai dengan karakteristik anak usia dini.

\section{DAFTAR PUSTAKA}

Borre, A. J., Bernhard, J., Bleiker, C., Winsler, A., Borre, A. J., Bernhard, J., ... Winsler, A. (2019). Preschool Literacy Intervention for Low-Income , Ethnically Diverse Children : Effects of the Early Authors Program Through Kindergarten Preschool Literacy Intervention for Low-Income , Ethnically Diverse Children : Effects of the Early Authors Program. Journal of Education for Students Placed at Risk (JESPAR), 24(2), 132-153. https://doi.org/10.1080/10824669.2019.1594818

Christianti, M. (2015). Membaca dan Menulis Permulaan Untuk Anak Usia Dini. Jurnal Pendidikan Anak. https://doi.org/10.21831/jpa.v2i2.3042

Darnis, S. (2018). Aplikasi Montessori Dalam Pembelajaran Membaca, Menulis Dan Berhitung Tingkat Permulaan Bagi Anak Usia Dini. Jurnal Caksana : Pendidikan Anak Usia Dini, 1(01). https://doi.org/10.31326/jcpaud.v1i01.3

Dhieni, N. (2013). Metode Pengembangan Bahasa (1st ed.). Tanggerang: Universitas Terbuka Jakarta. Fahrurrozi. (2017). Peningkatan Kemampuan Membaca Permulaan melalui Pendekatan Whole Language. Jurnal Pendidikan Usia Dini, 11(1), 165-180. 
https://doi.org/https://doi.org/10.21009/JPUD.072

Latifah, E. (2015). Peningkatan Kemampuan Menulis Puisi Bebas dengan Mteode Spalding Melalui Gambar. Universitas Pendidikan Indonesia.

Maqdalena, E., \& Widiastuti, A. A. (2018). Meningkatkan Kemampuan Simbol Huruf Melalui Permainan Ular Tangga Pada Anak Usia 5-6 Tahun Di Desa Dukuh Krajan Rt 09 Rw 01 Kelurahan Dukuh Kecamatan Sidomukti Kota Salatiga. Satya Widya: Jurnal Penelitian Pengembangan Pendidikan, 34(2), 125-137. https://doi.org/10.1017/CBO9781107415324.004

Mardliyah, S., Siahaan, H., \& Budirahayu, T. (2020). Pengembangan Literasi Dini melalui Kerjasama Keluarga dan Sekolah di Taman Anak Sanggar Anak Alam Yogyakarta. Jurnal Obsesi: Jurnal Pendidikan Anak Usia Dini, 4(2), 892. https://doi.org/10.31004/obsesi.v4i2.476

Matin, R., Rohaety, E., \& Nuraeni, L. (2019). Penerapan Media Pembelajaran POP-UP BOOK Anak Usia Dini Pada Kelompok B untuk, 2(2).

Moleong, L. J. (2016). Metodologi Penelitian Kualitatif (revisi). Bandung: Remaja Rosda Karya.

Morrison, G. S. (2012). Dasar-dasar pendidikan anak usia dini (PAUD). (S. Romadhona \& A. Widiastuti, Trans.) (Edisi keli). Jakarta: Indeks.

Nahdi, K., \& Yunitasari, D. (2019). Literasi Berbahasa Indonesia Usia Prasekolah: Ancangan Metode Dia Tampan dalam Membaca Permulaan. Jurnal Obsesi : Jurnal Pendidikan Anak Usia Dini, 4(1), 446. https://doi.org/10.31004/obsesi.v4i1.372

Neumann, M. M., Finger, G., \& Neumann, D. L. (2017). A Conceptual Framework for Emergent Digital Literacy. Early Childhood Education Journal, 45(4), 471-479. https://doi.org/10.1007/s10643-016-0792-z

Pinto, G., Bigozzi, L., Vezzani, C., \& Tarchi, C. (2017). Emergent literacy and reading acquisition: a longitudinal study from kindergarten to primary school. European Journal of Psychology of Education, 32(4), 571-587. https://doi.org/10.1007/s10212-016-0314-9

Purnama, R. (2019). Meningkatkan Penguasaan Keaksaraan Anak Usia Dini Melalui Media Flashcard di TK Para Bintang Kota Jambi Tahun Ajaran 2017-2018, 53(9), 1689-1699. https://doi.org/10.1017/CBO9781107415324.004

Rahmatika, P., Hartati, S., \& Yetti, E. (2019). Metode Pembelajaran Mind Map dan Bercerita dengan Gaya Kognitif, Pengaruhnya terhadap Kemampuan Membaca Permulaan. Jurnal Obsesi : Jurnal Pendidikan Anak Usia Dini, 3(2), 548. https://doi.org/10.31004/obsesi.v3i2.260

Simanjuntak, G. M., Widyana, R., \& Astuti, K. (2020). Pembelajaran Metode Multisensori Untuk Meningkatkan Kemampuan Pra-Membaca Pada Anak Usia Pra-Sekolah. Cakrawala Dini: Jurnal Pendidikan Anak Usia Dini, 11(1), 51-54. https:/ / doi.org/10.17509/cd.v11i1.21082

Spalding, R. B. (2012). The Writing Road to Reading: The Spalding Method for TeachingSpeech, Spelling, Writing, and Reading. New York: Collins Reference; Revised edition.

Sukma, A., Kurnia, R., \& Febrialismanto, F. (2020). Pengaruh Media Alphabet Smart terhadap Kemampuan Mengenal Huruf Anak Usia Dini. Aulad : Journal on Early Childhood, 3(1), 2935. https:// doi.org/10.31004/aulad.v3i1.50

Susanto, A. (2011). Perkembangan Anak Usia Dini (edisi 1). jakarta: Kencana.

Susanto, A. (2018). Pendidikan Anak Usia Dini (Konsep dan Teori) (edisi 2). Jakarta: Bumi Aksara.

Tjoe, J. O. L. (2012). Peningkatan Kemampuan Membaca Permulaan Melalui Pemanfaatan Multimedia, 17-48.

Winarti, W., \& Suryana, D. (2020). Pengaruh Permainan Puppet Fun terhadap Kemampuan Membaca Anak Usia Dini. Jurnal Obsesi: Jurnal Pendidikan Anak Usia Dini, 4(2), 873. https://doi.org/10.31004/obsesi.v4i2.462

Yin, R. K. (2015). Studi Kasus: Desain dan Metode. Jakarta: Rajawali Pers.

Yunita, N., Kurnia, R., \& Chairilsyah, D. (2020). Pengaruh Media Typewriter Alphabet terhadap Kemampuan Membaca Permulaan pada Anak Usia Dini. Aulad: Journal on Early Childhood, 3(1), 45-52. https://doi.org/10.31004/aulad.v3i1.51

Zuhrita, S., \& Mufidati, N. (2017). Permainan Dakon Writing Therapy Untuk Mengembangkan Kemampuan Dasar Menulis Anak Kelompok A TK Aisyiyah 33 Surabaya. PEDAGOGI: Jurnal Pendidikan Anak Usia DIni, 3, 85-89. 